\title{
Mathematical Anxiety and Its Relation to Engineering Student Achievement at Local University
}

\author{
Anisma Azwaty Azman \\ Faculty of Education, Universiti Kebangsaan Malaysia \\ E-mail: p96080@siswa.edu.my \\ Siti Mistima Maat (Correspondence) \\ Faculty of Education, Universiti Kebangsaan Malaysia \\ E-mail: sitimistima@ukm.edu.my
}

Received: February 14, 2021

doi: 10.5296/ire.v9i1.18302
Accepted: May 6, $2021 \quad$ Published: May 12, 2021

URL: https://doi.org/10.5296/ire.v9i1.18302

\begin{abstract}
Mathematical anxiety is a negative emotion experienced towards mathematics, which can influence a student's achievement in the subject. Therefore, the purpose of this study was to identify the relationship of mathematical anxiety with the achievement of engineering students at local universities. The design of the survey study used a quantitative approach and was conducted to obtain the necessary information. The Revised Mathematics Anxiety Rating Scale (RMARS) questionnaire containing 35 items and using a five-point Likert scale was distributed to a total of 293 respondents who were selected through simple random sampling. Data were analysed using descriptive analysis, and inference and regression. Statistical Package for Social Science (SPSS) software version 23.0 was used to analyse the study data and then answer the research questions. The findings of the study revealed that the level of mathematical anxiety among engineering students was at a high level. In addition, the study showed that there was no significant relationship between mathematical anxiety and achievement of engineering students in terms of RMARS $(\mathrm{r}=0.051, \mathrm{p}=0.381)$, GM $(\mathrm{r}=$ $0.102, \mathrm{p}=0.982), \mathrm{CM}(\mathrm{r}=0.074, \mathrm{p}=0.205)$, and SE $(\mathrm{r}=0.187, \mathrm{p}=0.001)$. A proposed improvement which could be implemented in future studies would be to increase the size of the sample and universities involved to study aspects of mathematical anxiety among engineering students. It is hoped that this study will be able to provide information to universities so that moral support can be provided to engineering students who have a high
\end{abstract}


level of mathematical anxiety. Furthermore, this study is also expected to be a guide for further research in an effort to identify the factors that motivate engineering students to overcome the problem of mathematical anxiety.

Keywords: Mathematical anxiety, Achievement, Engineering, Students

\section{Introduction}

Mathematics is an important subject at every level of study and is categorised as a basic subject for other science subjects (Divjak \& Tomic, 2011; Mohammad Ali \& Hassan, 2019). The goal of achieving a 60:40 ratio for students following the pure science stream planned by the government has yet to be fully achieved for this year. The existence of additional mathematics and mathematics subjects in this pure science stream is considered challenging and difficult for students to master (Chowdhury, 2014; Veloo, Md Ali, \& Krishnasamy , 2014). Concerns about maths further prevents students from following the pure trend even though they have clear academic qualifications (Fatin Aliah Phang, Mohd Salleh Abu, \& Mohammad Bilal Ali, 2014).

Mathematical anxiety can be defined as a feeling of being disturbed or experiencing discomfort when answering mathematics questions. Ashcraft and Faust (1994) state that mathematical anxiety is a feeling of stress or extreme anxiety that can disrupt the process of solving a mathematical question. In other words, it can also be seen when an individual is not convinced that they are capable of solving a mathematical problem and avoid engaging in any subject or field which involves mathematics (Sheffield \& Hunt, 2006). The problem of mathematical anxiety is not unfamiliar in schools and it is one of the common anxieties experienced by students (Ahmed, 2018).

An OECD report (2017) shows that on average 30\% of students in 65 countries belong to the group of students with a high level of mathematical anxiety (OECD, 2017). Unattended extreme mathematical anxiety will only leave a negative impact on students (Arem, 2003; Puteh, 2002). Studies show that the level of mathematical anxiety among students in Malaysia is at a moderate level (Khairulazuad, 2018; Puteh \& Khalin, 2016; Yahya \& Amir, 2018). Mathematical anxiety can be detected in six year old children from kindergarten to adulthood, specifically those who are studying at university (Beilock, Gunderson, Ramirez, \& Levine, 2010; Vukovic, Kieffer, Bailey, \& Harari, 2013). This increase in the level of mathematical anxiety is seen to be higher when children continue their studies to higher levels of education, starting with primary school, secondary school, and at university level (Dowker, Sarkar, \& Looi, 2016).

Prospective engineers who will work in the field of engineering still face difficulties in learning mathematics (Osman, Mohammad, Abu, \& Mokhtar (2020); Vitasari, Wahab, Herawan, Othman, \& Sinnadurai, 2010;). Engineering students were found to have a negative attitude in addition to a low level of understanding of the subject of mathematics (Kargar, Tarmizi, \& Bayat, 2010). They also believed that they were incapable of solving complex mathematical problems (Bates, Latham, \& Kim, 2011). Students who have difficulty solving maths questions will tend to feel embarrassed, inferior, confused, anxious, and have poor 
focus (Borwein \& Osborn, 2011).

However, it should be understood that the subject of mathematics is no stranger to engineering students. They need to use their mathematical understanding in the field of employment to explain the relevant physical, chemical, or formula aspects that they have learned throughout their study period (Vitasari et al., 2010). Because these mathematics subjects are the main subject of engineering students, they need a higher focus to ensure that they truly master the learning required. The need for high focus in this subject tends to lead to the existence of mathematical anxiety among students (Vitasari et al., 2010). Awareness of the existence of mathematical anxiety in engineering students can be explained by the fear, anxiety, loss of interest and focus, confusion, and stress experienced by the individuals involved (Gresham, 2010). Therefore, engineering students who are seen to have these symptoms should be given immediate attention and support by various parties including family, friends, and even the university.

The trend of mathematical anxiety analysed in 2018 shows several factors in its occurrence among university students. Factors that affect the mathematical anxiety of engineering students can be divided into three aspects, namely aspects at home, social aspects and those of the classroom (Rully Charitas Indra, Tri, Aji Prasetya, \& Ahmad Muhammad, 2019). Details of the classroom aspects discussed include the negative perceptions and behaviours of teachers in the classroom and the feelings of fear and anger that students experience when committing mathematical errors or when wanting to ask mathematics questions of teachers (Bekdemir, 2010). This statement is in line with the study of Sue (2017) who described that the impact of embarrassment because of teachers or peers as well as negative perceptions can make the student feel weak and lack confidence.

The social aspects mentioned in the study of Rully Charitas Indra et al. (2019) focus more on individual feelings or experiences as weak examples in basic mathematical concepts resulting in a person having negative experiences in the classroom (Maloney, Ansari, \& Fugelsang, 2011). These negative experiences felt by students tend to result in low levels of self-confidence and motivation which, in turn, affects their mathematical achievement (Emma et al., 2019; Jennifer, Myriam, \& Roberto, 2020). The perception of students that only selected peers who are capable of 'mathematical thinking' are able to answer mathematical questions well has damaged students' self-confidence to learn and succeed (Whyte \& Anthony, 2012). Such perceptions need to be eradicated at every level of study so that students do not turn this myth into one of the causes of their inability to answer mathematics questions.

The study of Livia et al. (2019) shows that mathematical anxiety is able to affect student achievement. Students with high levels of mathematical anxiety are said to be more likely to be low achievers in mathematical subjects while individuals with low levels of mathematical anxiety are more likely to obtain excellent marks (Hyun \& Wooyoul, 2019; Suharto \& Revelation, 2018). The increase in the level of mathematical anxiety among students can influence a person's ability to understand mathematics subject and in turn can result in negative effects on the learning of mathematics subjects and student achievement (Suharto \& Wahyu, 2018). 
In this conceptualization, mathematical anxiety is seen to affect an individual's cognitive function so that their mathematical information processing skills are affected (Ashcraft, Krause, \& Hopko, 2007). In addition to obtaining a variety of positive research findings which support the hypothesis that there is a significant relationship between mathematical anxiety and student achievement, there are several other research results that do not support these findings. Francesca, Irene, Amy, Sara, Maria and Chiara Passolunghi Denes (2016) found that there was no significant relationship between mathematical anxiety and student achievement. These findings are supported by several other studies showing a negative correlation between mathematical anxiety and student achievement (Heather \& Jo-Anne, 2017; Homoud, 2020; Puteh \& Khalin, 2016). Rully Charitas Indra et al., (2019) emphasise that these mathematical worries have no relation to student achievement, but they are able to have an indirect effect on student mathematical achievement.

This study was conducted to identify the relationship between mathematical anxiety and student achievement at a local university. This study was conducted on engineering students as they are a group that learns more mathematics subjects from various topics than students from other fields. This study is seen as more significant when conducted on engineering students as they need to use their mathematical knowledge in solving logical, analytical, critical, systematic, and creative thinking issues.

\section{Research Objective}

Based on the above statement, this study was conducted based on the following objectives:

1) To determine the level of mathematical anxiety among engineering students at a university in Selangor.

2) To identify the relationship between the level of mathematical anxiety and the achievement of engineering students at a university in Selangor.

3) To identify the contribution of mathematical anxiety to the achievement of engineering students at a university in Selangor.

\section{Methodology}

\subsection{Research Design}

The design of the survey study uses a quantitative approach which has been deployed by the researchers to obtain the desired data. Survey studies are deemed appropriate for use when researchers want to identify the relevant variables without questioning the existence of such variables of a phenomenon (Airasian \& Gay, 2000; Creswell, 2002). In addition, this method also saves the cost, energy, and time of researchers in obtaining a large number of samples for the purpose of data collection.

\subsection{Population and Samples}

This study involved a total of 293 engineering students (186 males, 107 females) at a public university in Malaysia. All respondents consisted of students at diploma level ( $\mathrm{n}=234$, $79.9 \%)$, bachelor's degree $(n=48,16.4 \%)$, and master's degree $(n=11,3.8 \%)$ in engineering 
$(\mathrm{n}=177,60.4 \%)$, technology engineering $(\mathrm{n}=54,18.4 \%)$, and social sciences $(\mathrm{n}=62$, 21.2\%). Simple random sampling methods have been used because each individual in this population has the same opportunity to be selected as the population representative (Fuad, 2017). The selection of engineering students as the study sample is based on the importance of mathematics subjects in engineering majors and engineering students are believed to use mathematics subjects more in learning.

\subsection{Instruments and Procedures}

The list of students pursuing engineering in public universities was identified before this questionnaire was distributed. Based on the list, the researcher sent an invitation email to the public university lecturer to participate in this study. The email included brief information about the study conducted along with special links that led to questionnaires in the form of Google Form that students needed to answer if they agreed to be involved as a sample of the study. One month was needed to distribute and obtain the data required by the researcher.

The instrument used in this study is the Revised Mathematics Anxiety Rating Scale (RMARS) which contains four constructs to measure mathematical anxiety and its relationship with student achievement. This instrument contains seven demographic items (gender, age, level of study, year of study, cumulative grade point average (CGPA), country, and institution of study), four constructs consisting of 18 items of the Revised Mathematics Anxiety Scale (RMARS), two items consisting of general thoughts about mathematics as it relates to engineering (GM), six items on 'choose the answer that resonates most with you with regard to the courses (CM), and nine items on 'how important do you think the following skills and abilities are to becoming a successful engineer? (SE) This questionnaire is based on the five-point Likert scale which represents the value for each of these items as 1: not at all worried, 2: not worried, 3: neutral, 4: worried, and 5: very worried. This instrument has undergone a process of validity and reliability testing through the study of Mustafa \& Paul (2007).

\subsection{Data Analysis}

Respondents who agreed to be involved in this study filled out the online consent form that was distributed by the researcher. The process of obtaining the permission and consent of the study respondents before they participated in this study was important to ensure that they understood all the information shared by the researcher and also that they agreed to participate in this research without any coercion (UNCST, 2007).

The data obtained by the researchers through the Google Form link was received and collected in the Microsoft Excel application before being analysed using Statistical Package for Social Scientist (SPSS) version 23.0. Normality, homoscedasticity, and linearity tests were conducted on the data obtained to meet the requirements of the parametric test. Non-parametric test analysis was applied as the assumptions could not be met and the results of the descriptive and inferential statistical analysis were displayed in tabular form.

The descriptive analysis of this study is explained through mean values and standard deviations. The interpretation of the mean score reading is based on Norasmah and Salmah's 
(2011) table while for inferential statistical analysis, Spearman's rho (r) correlation was used to identify if there was a relationship between mathematical anxiety and the achievement of engineering students in public universities in Malaysia. The reading of the $r$ value was based on the score table of the coefficients of Hinkle, Wiersma and Jurs (2003). After undertaking this analysis process, the researchers used a simple linear regression analysis to identify the contribution of mathematical anxiety to the achievement of engineering students at a university in Malaysia through the square value of the correlation coefficient $\square(r \Delta \wedge 2)$.

\section{Findings}

Level of mathematical anxiety among engineering students at a local university in Malaysia.

Descriptive analysis to identify the level of mathematical anxiety among engineering students in public universities in Malaysia was conducted based on the mean value, and standard deviation was conducted on 293 respondents involved in this study. The results of the study analysis can be seen in Table 1. The mean interpretation of each construct is based on Norasmah and Salmah's (2011) table.

The fourth construct 'how important do you think of the following skills and abilities to becoming a successful engineer?' (SE) - recorded the highest mean value reading $(\mu=4.067$, $\sigma=0.654$ ) while the first construct, Revised Mathematics Anxiety Scale (RMARS) recorded the lowest mean value reading $(\mu=3.735, \sigma=0.746)$. The second and third constructions respectively showed intermediate mean readings $(\mu=3.968, \sigma=0.735$, and $\mu=3.886, \sigma=$ 0.742). Based on these four constructs it has been confirmed that the level of mathematical anxiety among engineering students at a local university was high.

Table 1. Descriptive analysis for each construct of the Revised Mathematics Anxiety Scale

\begin{tabular}{|c|c|c|c|c|c|c|}
\hline Construct & $\begin{array}{l}\text { Number } \\
\text { of items }\end{array}$ & $\begin{array}{l}\text { Frequency } \\
(\mathrm{N})\end{array}$ & $\begin{array}{l}\text { Percent } \\
(\%)\end{array}$ & $\begin{array}{l}\text { Mean } \\
(\text { bi) }\end{array}$ & $\begin{array}{l}\text { Standard } \\
\text { deviation }(\sigma)\end{array}$ & Interpretation \\
\hline $\begin{array}{l}\text { (Revised Mathematics Anxiety Scale) } \\
\text { (RMARS) }\end{array}$ & 18 & 293 & 100 & 3.735 & 0.746 & High \\
\hline $\begin{array}{l}\text { (General thoughts about Mathematics } \\
\text { as it Relates to Engineering) (GM) }\end{array}$ & 2 & 293 & 100 & 3.968 & 0.735 & High \\
\hline $\begin{array}{l}\text { (Choose the answer that resonates most } \\
\text { with you with regard to the courses) } \\
\text { (CM) }\end{array}$ & 6 & 293 & 100 & 3.886 & 0.742 & High \\
\hline $\begin{array}{l}\text { (How important do you think the } \\
\text { following skills and abilities are to } \\
\text { becoming a successful engineer?) (SE) }\end{array}$ & 9 & 293 & 100 & 4.067 & 0.654 & Highest \\
\hline
\end{tabular}


The relationship between the level of mathematical anxiety and the achievement of engineering students at a public university in Malaysia

Spearman's rho (r) correlation analysis was conducted to identify the relationship between the level of mathematical anxiety and the achievement of engineering students in a public university in Malaysia. Interpretation of mean values is referred to using Norasmah and Salmah's (2011) table. Overall, there was no significant relationship for aspects of RMARS ( $\mathrm{r}$ $=0.051, \mathrm{p}=0.381, \mathrm{p}>0.05), \mathrm{GM}(\mathrm{r}=0.102, \mathrm{p}=0.982, \mathrm{p}>0.05), \mathrm{CM}(\mathrm{r}=0.074, \mathrm{p}=0.205$, $\mathrm{p}>0.05)$ on student achievement. Nevertheless, there was a significant relationship for the $\mathrm{SE}$ aspect $(\mathrm{r}=0.187, \mathrm{p}=0.001, \mathrm{p}>0.05)$. The strength of this relationship is positively weak. Therefore, H_o is rejected.

Table 2. Results of Spearman's rho correlation analysis for the relationship of mathematical anxiety with the achievement of engineering students at a public university in Malaysia.

Construct

Correlation Sig.

coefficient (r)

$(\mathrm{p}<0.05)$

1. Mathematical Anxiety Scale Revised

0.051

0.381

2. General view of mathematics and its relation to the field of engineering

0.102

0.082

3. Selection of answers related to yourself about the field

0.074

0.205

4. How important are the following skills and abilities to becoming a successful engineer?

\subsection{Contribution of Mathematical Anxiety to the Achievement of Engineering Students at a} Public University in Malaysia

Multiple regression analysis aims to measure the strengths and weaknesses of a relationship based on the correlation analysis that has been conducted. Overall, it was found that there was no significant correlation between mathematical concerns for aspects of RMARS, GM, $\mathrm{CM}$, and $\mathrm{SE}(\mathrm{F}=2.541, \mathrm{sig}=0.040, \mathrm{p}>0.05)$ on student achievement.

Analysis of multiple linear regression coefficients in Table 4 shows that mathematical anxiety for RMARS constructs $(b=.00 .045, t=11.009, p=0.314), G M(b=0.020, t=0.423, p=$ $0.672)$, and $\mathrm{CM}(\mathrm{b}=-0.003, \mathrm{t}=-0.059, \mathrm{p}=0.953)$ were found to show no significant relationship with student achievement. Nevertheless, the SE construct was seen to contribute to $3.4 \%$ ( $\mathrm{r}$ square) on student achievement $\left(\mathrm{r}^{\wedge} 2=0.034, \mathrm{p}=0.010\right)$. However, this contribution is considered almost non-existent for this study. 


\section{Discussion}

This study focuses on three main objectives. First, the researchers studied the level of mathematical anxiety among engineering students at a university in Malaysia. Second, the researcher investigated whether there was a significant relationship between mathematical anxiety and student achievement. Third, the researcher examined the contribution of mathematical anxiety to the achievement of engineering students in a public university in Malaysia.

\subsection{Level of Mathematical Anxiety Among Engineering Students at a Public University in Malaysia}

The findings of this study have shown that the level of anxiety among engineering students in a public university in Malaysia is high. This statement can be proven through item R16 of the RMARS construct, namely reactions recorded listening to a mathematics lecture which registered the highest mean value of 3.96 compared to other items, with $36.9 \%$ of respondents choosing very worried, $32.4 \%$ choosing worried, $22.5 \%$ choosing less sure, $4.4 \%$ choosing not worried and only $3.8 \%$ chose very not worried while listening to a mathematics lecture. These findings indicate that the majority of respondents are worried when listening or studying in mathematics lectures.

For the second construct of the study, 'general thoughts about mathematics as it relates to engineering (GM); this item recorded the highest mean value of 4.04 as in response to the statement 'I enjoy learning mathematics', $37.1 \%$ of respondents voted strongly agree, $33.6 \%$ voted agree, $25.7 \%$ chose less sure, $2.7 \%$ chose disagree and only $0.7 \%$ chose strongly disagree. The findings of this analysis illustrate that the respondents of this study enjoy learning the subject of mathematics even though they have feelings of worry about the subject.

The sixth item which is the statistics subject for the third construct, 'choose the answer that resonates most with you with regard to the courses' $(\mathrm{CM})$ or 'the selection of answers related to yourself in the field of engineering' recorded the highest mean of 3.98. The findings of the analysis showed that $35.2 \%$ of respondents chose the subject of statistics as an important subject, $32.4 \%$ chose very important, $30.4 \%$ chose uncertain, and $2 \%$ of respondents chose it as an unimportant subject in the field of engineering. None of the respondents chose the option indicating that they felt the subject was very insignificant. This confirms that the study respondents are aware that this subject is the most important subject in the field of engineering.

For the fourth construct, "how important do you think the following skills and abilities are to becoming a successful engineer'? (SE), the fifth item of cooperation (teamwork) recorded the highest mean value of 4.34 with $39.9 \%$ of respondents choosing important, followed by $32.4 \%$ choosing very important, $24.2 \%$ of respondents choosing uncertain, $2.7 \%$ voted unimportant, and only $0.7 \%$ of respondents voted very unimportant. These findings give the researcher an impression that the majority of respondents involved in this study believe that there are several skills and abilities that need to be mastered to become a successful engineer 
and the ability to work together has become the main choice of respondents as a skill that should be possessed by engineers.

Overall, the findings of this study relating to the level of mathematical anxiety among engineering students from local universities have shown that anxiety is high which coincides with the results of the study by Johnston-Wilder, Sue, Brindley, Den, and Philip (2014) which proved that $30 \%$ of the study group showed a high level of mathematical anxiety. Moreover, the study of Ashcraft \& Moore (2009) also supported this finding by asserting that $17 \%$ of the study population faces high levels of mathematical anxiety. Hyun and Wooyoul's study (2019) showed a high level of mathematical anxiety in the study sample, and also that the majority of students who experienced mathematical anxiety were among the students with the following characteristics: they find it easy to give up, they have negative perceptions of themselves, and they are not confident that they can solve mathematics problems even though they have tried.

However, this was in contrast to the findings of studies by Syed Ismail and Siti Mistima (2017); Puteh and Khalin (2016), Siti Zaharah Yahya and Ruslin Amir (2018) who found that the level of anxiety of students toward mathematics subjects was at a moderate level. The differences in the findings of this study according to researchers are due to different sample groups. The samples used in both studies were school students. At the school level, students are in the phase of knowledge stability where they are still learning to stabilise their emotions and behaviour while learning a subject (Livia et al., 2019) and they also have different learning experiences. Therefore, there are several other factors besides mathematical anxiety that is a good focus of school-level students.

\subsection{The Relationship Between the Level of Mathematical Anxiety and the Achievement of Engineering Students at a Public University in Malaysia}

The results of this study show that there is no significant relationship between mathematical anxiety and the achievement of engineering students. Analysis of the questionnaire found that $13.3 \%$ of students achieved CGPA between 3.50 and 4.00, 51.2\% achieved CGPA between 3.00 and 3.49 and the remaining $35.5 \%$ of students achieved CGPA between 0.00 and 2.99. These findings show that $64.5 \%$ of students have good CGPA achievement, which is between 3.00 and 4.00; more than half of the study respondents are in this range. Although the findings obtained through objective analysis show a high level of mathematical anxiety among students, no significant relationship between anxiety and student achievement was found.

This finding is also supported by the studies of Meryem and Murat (2019); Suharto andWahyu (2018) which both showed a negative correlation between mathematical anxiety and student achievement even though the number of study samples used was different. Not only that, the study of Livia et al. (2019) showed a positive relationship between mathematical anxieties and student achievement for aspects of mathematical calculation. The level of difficulty given was at a moderate to high level that required students to think. Therefore, this situation was believed to contribute to some extent and exposed students to mathematical concerns. 
However, these findings contradict the Deleterious Anxiety Model which explains the existence of a relationship between high levels of mathematical anxiety and low achievement (Emma et al., 2019). This situation is explained by the anxiety experienced by students towards the subject of mathematics. These feelings have disrupted the learning process and recalled what students have learned in the classroom (Ashcraft \& Kirk, 2001; Ashcraft et al., 2007). In addition, the OECD (2013) report also showed a positive relationship between mathematical anxiety and student achievement. However, there are some questions or factors that are still unanswered: for example, can mathematical anxiety affect other individuals? Or if the teacher has provided teaching materials that suit the needs of the students but the students still get low results, what is the cause of the low achievement? These questions are among those that have not been answered in the PISA report and that still challenge researchers.

\section{Limitations}

The main limitation in the study conducted by the researchers is the small sample size. Therefore, the same findings cannot be guaranteed if the study were conducted on a larger sample size. In addition, the survey questionnaire was also distributed online. Researchers were not able to communicate directly or face-to-face with the study respondents if they had problems or difficulties in answering the questionnaires. In addition, this study was only conducted on engineering students at a local university without taking into account engineering students from other universities.

\section{Implications}

Overall, it has been proven that there is no significant relationship between mathematical anxiety and student achievement. However, it should be noted that the findings indicate that the level of mathematical anxiety among engineering students is high. This means that the problem of mathematical anxiety exists among students at the university. Therefore, proactive measures need to be taken by the university, faculty, teachers, parents, and even the individual to ensure that this mathematical anxiety problem does not have a negative impact. At the university level, special subjects dealing with the problems of mathematical anxiety can be created as one of the efforts to show students ways to deal with anxiety and difficulty in learning mathematics subjects. In addition, regular special check-ups can also be carried out to check the level of emotional and mental health of students so that their health is always in optimal condition. Apart from getting outside help, individuals suffering from anxiety also need to protect themselves to the best of their ability to ensure that mathematical anxiety does not affect their daily lives. Individuals need to focus on the successes that they have achieved throughout the learning period rather than looking at the failures that have been encountered. In addition, with the support and assistance of the university, teachers and parents, it is hoped that students can strengthen their spirit and change the perception of failure from negative to positive, so that their lives are more prosperous and not stressed.

\section{Conclusion}

A study on the relationship between mathematical anxiety and achievement of engineering 
students was conducted at a public university in Malaysia. The study sample was a total of 293 students from various levels of study. Researchers are confident that if this study was conducted with a larger sample number as well as involving several other public universities, then the findings of the study would be more accurate and could be generalised to the study population. Overall, it can be concluded that this study shows that there is no significant relationship between mathematical anxiety and achievement of engineering students in a university in Malaysia.

\section{Acknowledgement}

This research was funded by the grant GG-2020-016 of Faculty Education, Universiti Kebangsaan Malaysia.

\section{References}

Airasian, P., \& Gay, L. (2000). Educational research: Competencies for analysis and application (6th Edition). New Jersey: Prentice-Hall Inc.

Arem, C. (2003). Conquering math anxiety. California: Brooks/Col Thomasan Learning.

Ashcraft, M. H., \& Faust, M. (1994). Mathematics anxiety and mental arithmetic performance: An exploratory investigation. Journal of Cognition and Emotion, 8, 97-125. https://doi.org/10.1080/02699939408408931

Ashcraft, M. H., \& Kirk, E. P. (2001). The relationship among working memory, math anxiety and performance. Journal of Experimental Psychology General, 130(2), 224-237. https://doi.org/10.1037/0096-3445.130.2.224

Ashcraft, M. H, Krause, J., \& Hopko, D. (2007). Is math anxiety a mathematical learning disability? Paul H Brookes Publishing.

Ashcraft, M. H., \& Moore, A. M. (2009). Mathematics anxiety and the affective drop in performance. Journal of Psychoeducational Assessment, 27(3), 197-205. https://doi.org/10.1177/0734282908330580

Bates, A. B., Latham, N., \& Kim, J. (2011). Linking preservice teachers' mathematics self-efficacy and mathematics teaching efficacy to their mathematical performance. School of Science and Mathematics, 111, 325-333. https://doi.org/10.1111/j.1949-8594.2011.00095.x

Beilock, S., Gunderson, E., Ramirez, G., \& Levine, S. (2010). Female teachers' math anxiety affects girls' math achievement. In Proceedings of the National Academy of Sciences of the United States of America (pp. 107 [5], 1860-1863). https://doi.org/10.1073/pnas.1003899107

Bekdemir, M. (2010). The pre-service teachers' mathematics anxiety related to depth of negative experiences in mathematics classroom while they were students. Educational Studies in Mathematics, 75(3), 311-328. https://doi.org/10.1007/s10649-010-9260-7

Borwein, J., \& Osborn, J. (2011). Loving and hating mathematics by Reuben Hersh and Vera John-Steiner. Math Intelligencer, 33, 63-69. https://doi.org/10.1007/s00283-011-9260-1 
Chowdhury, S. (2014). A study on mathematics anxiety among the 9th and 10th grade secondary school students of Tinsukia district in Assam, India. The Clarion International Multidiscipinary Journal, 3(1), 51-60.

Creswell, J. W. (2002). Educational research: Planning, conducting and evaluating quantitative and qualitative research. Upper Saddle River, NJ: Merril Prentice Hall, Inc.

Divjak, B., \& Tomic, D. (2011). The impact of game-based learning on the performance of learning goals and motivation for learning mathematics. Journal of Information and Organizational Sciences, 35(1), 15-30.

Dowker, A., Sarkar, A., \& Looi, C. (2016). Mathematics Anxiety: What we have learned in 60 years? Frontiers in Psychology. Retrieved from https://doi.org/10.3389/fpsyg.2016.00508

Emma, C., Amy, D., Francesca, H., Ann, D., Ros, M., \& Denes, S. (2019). Understanding Mathematics Anxiety: Investigating the experiences of UK primary and secondary school students. Centre of Neuroscience in Education.

Fatin Aliah Phang, Mohd Salleh Abu, \& Mohammad Bilal Ali. (2014). Faktor penyumbang kepada kemerosotan penyertaan pelajar dalam aliran sains: satu analisis sorotan tesis. Sains Humanika, 2(4), 63-71. https://doi.org/10.14221/ajte.2011v36n3.2

Francesca, H., Irene, C. M., Amy, D., Sara, C., \& Maria, Chiara Passolunghi Denes, S. (2016). Maths anxiety in primary and secondary school students: Gender differences, developmental changes and anxiety specificity. Learning Individual Differences.

Gresham, G. (2010). A study exploring exceptional education pre-service teachers' mathematics anxiety. Issues in the Undergraduate Mathematics Preparation of School Teachers, 4, 1-14.

Heather, P. D., \& Jo-Anne, L. (2017). Exploring the influence of basic cognitive skills on the relation between math performance and math anxiety. Journal of Numerical Cognition, 3(3), 642-666. https://doi.org/10.5964/jnc.v3i3.113

Hinkle, Wiersma, \& Jurs. (2003). Applied statistics for the behavioral sciences (5th Edition).

Homoud, M. N. A. (2020). The effects of active recreational maths games on maths anxiety and performance in Primary school children: An experimental study. Journal for Education, Social and Technological Sciences, 7(1), 89-112. https://doi.org/10.4995/muse.2020.12622

Hyun, S. Y., \& Wooyoul, N. (2019). How are maths-anxious students identified and what are the key predictors of maths anxiety? Insights gained from PISA results for Korean adolescents. Asia Pacific Journal of Education.

Jennifer, L. B., Myriam, O.-P., \& Roberto, S.-V. (2020). Does mathematical anxiety differ cross-culturally? Journal of New Approaches in Educational Research, 9(1), 126-136. https://doi.org/10.7821/naer.2020.1.464

Johnston-Wilder, Sue, Brindley, Den, J., \& Philip. (2014). A survey of mathematics anxiety and mathematical resilience among existing apprentices. London: Gatsby Charitable 
Foundation.

Kargar, M., Tarmizi, R. A., \& Bayat, S. (2010). Relationship between mathematical thinking, mathematics anxiety and mathematics attitudes among university students. Procedia Social and Behavioral Sciences, 8, 537-542. https://doi.org/10.1016/j.sbspro.2010.12.074

Khairulazuad, H. (2018). Kebimbangan matematik dengan pencapaian matematik dan faktor demografi dalam kalangan pelajar matrikulasi. Jurnal Penyelidikan Dedikasi, 14, 89-121.

Livia, B., Massimo, P., Gianni, A. L., Silvia, I., Chiara, B., \& Sandro, E. (2019). Mathematics anxiety and cognitive performance in adolescent students. Journal of Danubian Psychiatric Association, 31(3), 479-485.

Maloney, E., Ansari, D., \& Fugelsang, J. (2011). The effect of mathematics anxiety on the processing of numerical magnitude. Journal of Experimental Psychology, 64(1), 10-16. https://doi.org/10.1080/17470218.2010.533278

Meryem, C., \& Murat, T. (2019). Anxiety about mathematics among university students: A multi-dimentional study in the 21st century. Cypriot Journal of Educational Science, 14(2), 222-231. https://doi.org/10.18844/cjes.v14i2.4217

Mohammad Ali, N. A., \& Hassan, N. C. (2019). Mathematics anxiety and mathematics motivation among students in the Faculty of Science of a public university in Malaysia. Journal of Academic Research in Progressive Education and Development, 8(4), 952-963. https://doi.org/10.6007/IJARPED/v8-i4/6786

Mustafa, B., \& Paul, F. Z. (2007). Psychometric properties of the revised mathematics anxiety rating scale. The Psychological Record, 57(4), 593-611. https://doi.org/10.1007/ BF03395597

Norasmah, O., \& Salmah, I. (2011). Kecenderungan terhadap pemilihan kerjaya keusahawanan mengikut persepsi peserta skim usahawan siswa. Jurnal Teknologi, 56, 47-63. https://doi.org/10.11113/jt.v56.59

OECD. (2013). PISA 2012 Assessment and analytical framework: Mathematics, Reading,

Science, Problem solving and Financial literacy. OECD Publishing. https://doi.org/10.1787/9789264190511-en

OECD. (2017). PISA 2015 Results (Volume III): Students' Well-Being (Vol. III). Paris: OECD Publishing. https://doi.org/10.1787/g257ae7a02-en

Osman, S., Mohammad, S., Abu, M. S., \& Mokhtar, M. (2020). A Grounded-Theory Study of Civil Engineering Design Practice in Malaysia. Journal of Civil Engineering Education, 146(2), 04019004. https://doi.org/10.1061/(ASCE)EI.2643-9115.0000007

Puteh, M. (2002). Factors associated with mathematics anxiety. Tanjong Malim: Universiti Pendidikan Sultan Idris.

Puteh, M., \& Khalin, S. (2016). Mathematics anxiety and its relationship with the achievement of secondary students in Malaysia. Journal of Social Science and Humanity, 
6(2), 119-122. https://doi.org/10.7763/IJSSH.2016.V6.630

Rully Charitas Indra, P., Tri, S., Aji Prasetya, W., \& Ahmad Muhammad, D. (2019). Mathematical anxiety among engineering students. Journal of Mathematics Education, 8(2), 179-188. https://doi.org/10.22460/infinity.v8i2.p179-188

Sheffield, D., \& Hunt, T. (2006). How does anxiety influence maths performance and what can we do about it? https://doi.org/10.11120/msor.2006.06040019

Sue, W. (2017). Maths Anxiety: The nature and consequences of shame in mathematics classroom. In Proceeding of the 40th Annual Conference of the Mathematics Education Research Group Autralasia (pp. 562-568).

Suharto, S., \& Wahyu, W. (2018). The students' anxiety in facing the mathematical national exams. Journal of Education and Humanities Research, 253, 123-124.

Syed Ismail, S. A., \& Maat, S. M. (2017). Hubungan antara kebimbangan terhdap matematik dengan pencapaian dalam kalangan pelajar sekolah rendah.

UNCST (2007). National guidelines for research involving humans as research participants. Uganda National Council for Science and Teachnology. Kampala, Uganda.

Veloo, A., Md Ali, R., \& Krishnasamy, H. (2014). Affective determinants of additional mathematics achievement in Malaysian technical secondary schools. Procedia Social and Behavioral Sciences, 112(1), 613-620. https://doi.org/10.1016/j.sbspro.2014.01.1208

Vitasari, P., Wahab, M. N. A., Herawan, T., Othman, A., \& Sinnadurai, S. K. (2010). Exploring mathematics anxiety among engineering students. Procedia Social and Behavioral Sciences, 8, 482-489. https://doi.org/10.1016/j.sbspro.2010.12.066

Vukovic, R., Kieffer, M., Bailey, S., \& Harari, R. (2013). Mathematics anxiety in young children: Concurrent and longitudinal associations with mathematical performance. Contemporary Educational Psychology, 38(1), 1-10. https://doi.org/10.1016/j.cedpsych. 2012.09.001

Whyte, J., \& Anthony, G. (2012). Maths anxiety: The fear factor in the mathematics classroom. New Zealand Journal of Teachers' Work, 9(1), 6-15.

Yahya, S. Z., \& Amir, R. (2018). Kebimbangan matematik dan pencapaian matematik tambahan. Journal of Nusantara Studies, 3(2), 124-133. https://doi.org/10.24200/jonus. vol3iss2pp124-133

\section{Copyright Disclaimer}

Copyright reserved by the authors.

This article is an open-access article distributed under the terms and conditions of the Creative Commons Attribution license (http://creativecommons.org/licenses/by/4.0/). 